\title{
Can fertilization with sewage sludge contaminate pineapple fruits with phthalates?
}

\author{
A adubação com lodo de esgoto pode contaminar os frutos de abacaxizeiro com ftalatos? \\ ¿Puede la fertilización con lodos de depuradora contaminar los frutos de la piña con ftalatos?
}

Received: 06/28/2021 | Reviewed: 07/07/2021 | Accept: 07/10/2021 | Published: 07/22/2021

\author{
Izabelle de Paula Sousa \\ ORCID: https://orcid.org/0000-0002-5176-4612 \\ Federal University of Viçosa, Brazil \\ E-mail: izabelle.sousa@ufv.br \\ Ana Luiza Santos de Oliveira \\ ORCID: https://orcid.org/0000-0002-8764-9309 \\ Federal University of Minas Gerais, Brazil \\ E-mail: analuizasdo@hotmail.com \\ Paulo Henrique Silveira Cardoso \\ ORCID: https://orcid.org/0000-0002-6209-7026 \\ University of São Paulo, Brazil \\ E-mail: paulohenrique.sc@hotmail.com \\ Regynaldo Arruda Sampaio \\ ORCID: https://orcid.org/0000-0003-3214-6111 \\ Federal University of Minas Gerais, Brazil \\ E-mail: regynaldo@terra.com.br \\ Fernanda Laurinda Valadares Ferreira \\ ORCID: https://orcid.org/0000-0003-3206-8467 \\ Federal University of Viçosa, Brazil \\ E-mail: fernanda_laurinda@yahoo.com.br \\ Geraldo Ribeiro Zuba Junio \\ ORCID: https://orcid.org/0000-0003-1368-8257 \\ Federal University of Minas Gerais, Brazil \\ E-mail: juniozuba@yahoo.com.br
}

\begin{abstract}
The aim of the present study was to evaluate the phthalate content in the soil and in the pineapple fruit fertilized with different types of sewage sludge and mineral fertilizer. The experiment was carried out in a greenhouse, in randomized block design, with seven treatments and three replications. The treatments were: control $(\mathrm{C})$, mineral fertilization (MF), fertilizations with solarized sewage sludge (SS), sanitized sewage sludge with calcium oxide (CaS), dried sewage sludge (DS), composted sewage sludge (CS), and vermicomposted sewage sludge (VS). The contents of dimethyl phthalate (DMP), dibutyl phthalate (DBP), and diethyl hexyl phthalate (DEHP) in the soil and in the pineapple pulp were analyzed. Fertilization with sewage sludge sanitized with calcium oxide $\left(0.012 \mathrm{mg} \mathrm{kg}^{-1}\right)$, dried $\left(0.017 \mathrm{mg} \mathrm{kg}^{-1}\right)$, and solarized $\left(0.031 \mathrm{mg} \mathrm{kg}^{-1}\right)$ provided the lowest levels of DMP in the soil, while the sewage sludge sanitized with calcium oxide $\left(0.046 \mathrm{mg} \mathrm{kg}^{-1}\right)$, dried $\left(0.054 \mathrm{mg} \mathrm{kg}^{-1}\right)$, solarized $\left(0.063 \mathrm{mg} \mathrm{kg}^{-1}\right)$, and vermicompost $\left(0.076 \mathrm{mg} \mathrm{kg}^{-1}\right)$ provided the lowest levels of DEHP in pineapple pulp. Sludge fertilizations maintained the levels of DMP, DBP, and DEHP in soils, below the maximum limits for prevention, established by Brazilian environmental legislation. In addition, all phthalates levels in the pineapple pulp were below the critical safety limits for this food consumption.
\end{abstract}

Keywords: Biosolid; Environmental contamination; Dimethyl phthalate; Dibutyl phthalate; Diethyl hexyl phthalate; Toxic organic substances.

\section{Resumo}

O objetivo deste estudo foi avaliar os teores de ftalatos no solo e no fruto do abacaxizeiro adubado com diferentes tipos de lodos de esgotos e fertilizante mineral. O experimento foi conduzido em casa de vegetação, no delineamento em blocos casualizados, com sete tratamentos e três repetições. Os tratamentos foram: controle (C); adubação mineral (MF); adubação com lodo de esgoto solarizado (SS), lodo de esgoto caleado (CaS), lodo de esgoto seco em secadora (DS), lodo de esgoto compostado (CS) e lodo de esgoto vermicompostado (VS). Os teores de dimetil ftalato (DMP), dibutil ftalato (DBP) e dietil hexil ftalato (DEHP) no solo e na polpa de abacaxi foram analisados. As adubações com lodo de esgoto caleado $\left(0,012 \mathrm{mg} \mathrm{kg}^{-1}\right)$, secado em secadora $\left(0,017 \mathrm{mg} \mathrm{kg}^{-1}\right)$ e solarizado $\left(0,031 \mathrm{mg} \mathrm{kg}^{-1}\right)$ proporcionaram os menores teores de DMP no solo, enquanto o lodo de esgoto caleado $\left(0,046 \mathrm{mg} \mathrm{kg}^{-1}\right)$, secado em secadora $\left(0,054 \mathrm{mg} \mathrm{kg}^{-1}\right)$, solarizado $\left(0,063 \mathrm{mg} \mathrm{kg}^{-1}\right)$, e o vermicomposto $\left(0,076 \mathrm{mg} \mathrm{kg}^{-1}\right)$ proporcionaram os menores teores de DEHP na polpa de abacaxi. As adubações com lodos mantiveram os teores de DMP, DBP e DEHP nos solos, abaixo dos limites máximos para prevenção estabelecidos pela legislação ambiental brasileira. Além disso, os 
teores de todos os ftalatos na polpa de abacaxi ficaram abaixo dos limites críticos de segurança para o consumo desse alimento.

Palavras-chave: Biossólidos; Contaminação ambiental; Dimetil ftalato; Dibutil ftalato; Dietil hexil ftalato; Substâncias orgânicas tóxicas.

\section{Resumen}

El objetivo de este estudio fue evaluar los niveles de ftalatos en el suelo y en el fruto de piña fertilizada con diferentes tipos de lodos de depuradora y fertilizante mineral. El experimento se realizó en invernadero, en un diseño de bloques al azar, con siete tratamientos y tres repeticiones. Los tratamientos fueron: control (C); fertilizante mineral (MF); fertilización con lodos de depuradora solarizados (SS), lodos de depuradora encalados (CaS), lodos de depuradora secos en secado (DS), lodos de depuradora compostados (CS) y lodos de depuradora con vermicompostaje (VS). Se analizaron los contenidos de dimetil ftalato (DMP), dibutil ftalato (DBP) y dietil hexil ftalato (DEHP) en suelo y pulpa de piña. La fertilización con lodos de depuradora encalados $\left(0,012 \mathrm{mg} \mathrm{kg}^{-1}\right)$, secado en secadora $\left(0,017 \mathrm{mg} \mathrm{kg}^{-1}\right)$ y solarizado $\left(0,031 \mathrm{mg} \mathrm{kg}^{-1}\right)$ proporcionó los niveles más bajos de DMP en el suelo, mientras que los lodos de depuradora encalados $\left(0,046 \mathrm{mg} \mathrm{kg}^{-1}\right)$, secado en secadora $\left(0,054 \mathrm{mg} \mathrm{kg}{ }^{-1}\right)$, solarizado $\left(0,063 \mathrm{mg} \mathrm{kg}^{-1}\right)$ y vermicompost $\left(0,076 \mathrm{mg} \mathrm{kg}^{-1}\right)$ proporcionaron los niveles más bajos de DEHP en la pulpa de piña. La fertilización con lodos mantuvo los contenidos de DMP, DBP y DEHP en el suelo por debajo de los límites máximos de prevención establecidos por la legislación ambiental brasileña. Además, el contenido de todos los ftalatos en la pulpa de la piña estaba por debajo de los límites críticos de seguridad para el consumo de este alimento.

Palabras clave: Biosólidos; Contaminación ambiental; Ftalato de dimetilo; Ftalato de dibutilo; Ftalato de dietilhexilo; Sustancias orgánicas tóxicas.

\section{Introduction}

The basic sanitation sector, aiming to meet environmental requirements regarding the solid waste management, faces difficulties with the final destination of sewage sludge, since the waste must be correctly disposed, either in landfills, incinerated or even applied in agriculture (Song et al. 2013, Santos et al. 2017). Studies show that sewage sludge has been u sed in agriculture because it is a compound rich in organic matter (OM) and nutrients, mainly nitrogen and phosphorus (Melo et al. 2018, Florentino et al. 2019).

Among several crops produced in Brazil, pineapple production reached 1.6 million tons of 2019 (IBGE, 2019). Pineapple is a fruit plant with high nutritional demand, mainly for nitrogen (Leonardo et al. 2019). Thus, sewage sludge and its derivatives can be used as nutrients source for this crop and as alternative in order to reduce its production costs (Mota et al. 2018).

However, one of the biggest obstacles to the sewage sludge application in agriculture is the contaminants presence in its composition, such as toxic organic compounds (Ignatowicz, 2017, Urbaniak et al. 2017). Among them, phthalate esters or just phthalates can be mentioned, which are chemical compounds used as plasticizers due to the benefits they provide to the final product such as flexibility and elasticity (Chang et al. 2021).

These substances may belong to the short alkyls group, such as dimethyl phthalate (DMP) and dibutyl phthalate (DBP), which are soluble in water, and the long alkyls group, such as diethyl hexyl phthalate (DEHP), which is less soluble in water and more recalcitrant. Some studies report that the exposure of these compounds to humans, especially pregnant women and fetuses, causes adverse health effects. However, they are prone to biodegradation, photodegradation and anaerobic degradation, which means that most of them do not persist for long in the environment (Chen et al. 2017a, Karačonji et al. 2017, Li et al. 2019, Podlecka et al. 2020).

Therefore, in order to reduce sewage sludge contaminants and make its use feasible in agricultural systems, it is necessary to sanitize (clean) it through physical, chemical, and/or biological processes, which cause changes in the nutrients bioavailability, in pathogens reduction and odor. There are some methods used for this purpose, as composting, churning, drying at high temperatures, solarization and vermicomposting, all of which promote changes in the physical and chemical characteristics of this residue (Nascimento et al. 2014, Martín-Díaz et al. 2020).

In this context, the aim of the present research was to evaluate the phthalates content in soil and in pineapple fruits 
pulp fertilized with sewage sludge derived from different hygiene processes.

\section{Material and Methods}

\subsection{Experiment location and climatic characteristics}

The experiment was conducted from November 2014 to September 2016, in a greenhouse at the Institute of Agricultural Sciences (ICA) of the Federal University of Minas Gerais (UFMG), Montes Claros, Brazil, with latitude $16^{\circ} 40 '$ 58" S, longitude $43^{\circ} 50^{\prime} 25^{\prime \prime} \mathrm{W}$ and "Aw" climatic classification (hot tropical with dry winter), according to Köppen (Alvares et al. 2013).

\subsection{Cultivated variety and soil attributes}

The pineapple seedlings of cultivar Pérola (Ananas comosus var. Comosus) were planted in soil samples from Cambissolo Háplico, belonging to the fruit cultivation area of the institution, whose chemical and physical attributes of the 0$20 \mathrm{~cm}$ deep layer are shown in Table 1.

Table 1. Chemical and physical attributes of the Cambisolo Háplico used in the experiment.

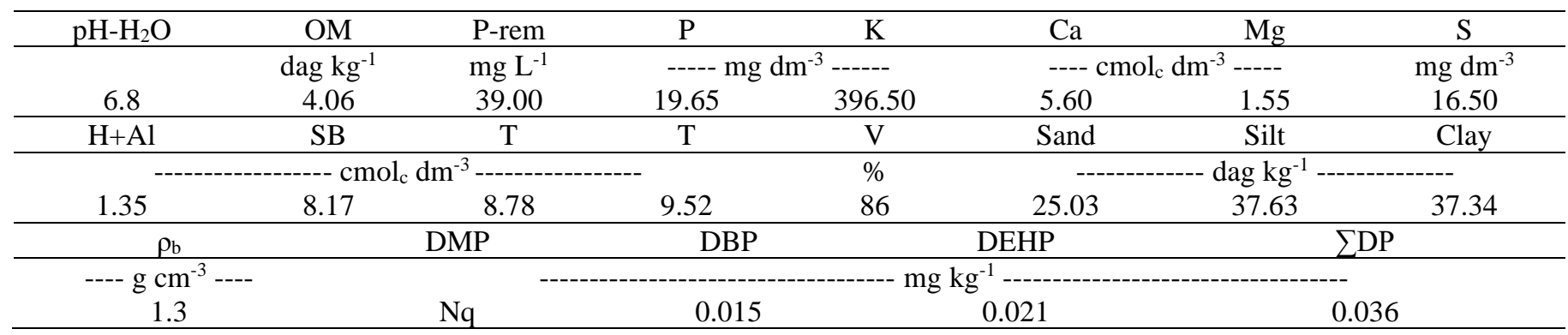

Note: phthalate levels were determined according to the methodologies of Pereira et al. (2019), while the other attributes were determined according to Embrapa methodologies (1997), $\mathrm{MO}=$ organic matter, $\mathrm{P}-\mathrm{rem}=$ phosphorus remaining, $\mathrm{SB}=$ sum of bases, $\mathrm{t}=$ effective cation exchange capacity, $\mathrm{T}=$ total cation exchange capacity, $\mathrm{V}=$ base saturation percentage, $\rho \mathrm{b}=$ bulk density (soil), $\mathrm{nq}=$ not quantified, $\mathrm{DMP}=$ dimethyl phthalate, DBP $=$ dibutyl phthalate, $\mathrm{DEHP}=$ diethyl hexyl phthalate, $\Sigma \mathrm{DP}=\mathrm{DMP}+\mathrm{DBP}+\mathrm{DEHP}$. Source: Authors.

\subsection{Experiment installation}

The experiment was arranged in randomized blocks with seven treatments and three replications, totaling 21 experimental units. The treatments were: control $(\mathrm{C})$, mineral fertilization $(\mathrm{MF})$, fertilizations with solarized sewage sludge (SS), sanitized sewage sludge with calcium oxide (CaS), sewage sludge dried in a dryer (DS), composted sewage sludge (CS), and vermicomposted sewage sludge (VS).

The NPK fertilization (MF) was based on crop requirement and soil chemical analysis (Souza et al., 1999), using 20.0 $\mathrm{g}$ of urea per plant $\left(9.0 \mathrm{~g}\right.$ of $\mathrm{N}$ per plant), $16.7 \mathrm{~g}$ of single superphosphate per plant $\left(3.0 \mathrm{~g}\right.$ of $\mathrm{P}_{2} \mathrm{O}_{5}$ per plant $)$, and $8.6 \mathrm{~g}$ of $\mathrm{KCl}$ per plant $\left(5.0 \mathrm{~g}\right.$ of $\mathrm{K}_{2} \mathrm{O}$ per plant).

The sewage sludge used in the present research came from the Sewage Treatment Station of Montes Claros city, MG, called "ETE - Vieira". The ETE consists of preliminary treatment stages followed by an Upflow Anaerobic Sludge Blanket (UASB) and subsequent centrifugation of the sludge generated in the reactor (85\% of moisture).

For the application of this sewage sludge in the soil, different sanitation processes were carried out to allow its safe use in the pineapple cultivation. Thus, the solarized sludge (SS) was obtained by drying the centrifuged sludge, in full sun, for 30 days, in a $30 \mathrm{~cm}$ layer. The sanitized sewage sludge with calcium oxide $(\mathrm{CaS})$ originated by the addition of calcium oxide $(\mathrm{CaO})$ in $50 \%$ proportion of sewage sludge dry mass, the dehydrated sludge was dried in a dryer at $350{ }^{\circ} \mathrm{C}$ for 30 min. The 
composted sludge resulted from the mixture of the centrifuged sludge to the grass pruning (Paspalum notatum) in the ratio of 1:5 m/m, to obtain C/N ratio of 30/1. The vermicomposted sludge was obtained using California Red earthworms (Eisenia foetida) in a pre-compound obtained from the mixture of the previous treatment, but with only one month of compost. The chemical attributes of the sludge after the cleaning processes are shown in Table 2.

Table 2. Chemical attributes of sewage sludge with different sanitization processes and the respective phthalates contribution by applying this residue to the soil $(n=3)$

\begin{tabular}{|c|c|c|c|c|c|c|}
\hline \multirow{2}{*}{ Variable } & \multicolumn{5}{|c|}{ Sewage Sludge } & \multirow{2}{*}{ Unit } \\
\hline & SS & $\mathrm{CaS}$ & DS & $\mathrm{CS}$ & VS & \\
\hline $\mathrm{N}$ - available & 5.70 & - & 6.77 & 3.70 & 3.80 & $\mathrm{mg} \mathrm{kg}^{-1}$ \\
\hline DOSE & 1.58 & 0.03 & 1.33 & 2.43 & 2.37 & $\mathrm{~kg}$ plant ${ }^{-1}$ \\
\hline \multirow[t]{2}{*}{ DMP } & 0.027 & 0.004 & 0.008 & 0.020 & 0.014 & $\mathrm{mg} \mathrm{kg}^{-1}$ \\
\hline & $(0.043)$ & $(0.0001)$ & $(0.011)$ & $(0.049)$ & $(0.033)$ & $m g$ pot $^{-1}$ \\
\hline \multirow[t]{2}{*}{ DBP } & 0.018 & 0.078 & 0.008 & 0.021 & 0.018 & $\mathrm{mg} \mathrm{kg}^{-1}$ \\
\hline & $(0.028)$ & $(0.002)$ & $(0.011)$ & $(0.051)$ & $(0.043)$ & $\mathrm{mg} \mathrm{pot}-1$ \\
\hline \multirow[t]{2}{*}{ DEHP } & 0.579 & 5.044 & 0.122 & 0.05 & 0.222 & $\mathrm{mg} \mathrm{kg}^{-1}$ \\
\hline & $(0.915)$ & $(0.151)$ & $(0.162)$ & $(0.122)$ & $(0.526)$ & $\mathrm{mg}$ pot $^{-1}$ \\
\hline \multirow[t]{2}{*}{$\sum \mathrm{DP}$} & 0.624 & 5.126 & 0.138 & 0.091 & 0.254 & $\mathrm{mg} \mathrm{kg}^{-1}$ \\
\hline & $(0.986)$ & $(0.154)$ & $(0.184)$ & $(0.221)$ & $(0.602)$ & $\mathrm{mg}$ pot $^{-1}$ \\
\hline
\end{tabular}

Note: phthalate levels were determined according to the methodologies of Pereira et al. (2019), while the N-available was determined and calculated as described in Brazil (2006), SS = solarized sewage sludge, CaS = sanitized sewage sludge with calcium oxide, DS = dried sewage sludge, $\mathrm{CS}=$ composted sewage sludge, VS = vermicomposted sewage sludge, $\mathrm{N}$-available $=$ available nitrogen content, dose $=$ refers to the amount of sewage sludge applied per vessel, DMP $=$ Dimethyl phthalate, DBP = Dibutyl phthalate, DEHP = Diethyl hexyl phthalate, $\sum \mathrm{DP}=\sum \mathrm{DMP}+\mathrm{DBP}+\mathrm{DEHP}$. Values in parentheses represent the amount of each substance added to the soil by the sewage sludge application. Source: Authors.

The CaS dose was $31.28 \mathrm{~g}$ per plant and corresponded to the amount applied in which the final $\mathrm{pH}$ of the soil-sludge mixture did not exceed the limit of 7.0. For the other sewage sludge treatments, the applied amounts were based on the nitrogen content available in the residues (Table 2). For subsurface application (Brazil, 2006) and on the pineapple requirement for this nutrient (Souza et al. 1999), being applied: $2.43 \mathrm{~kg}$ of CS per plant, $2.37 \mathrm{~kg}$ of VS per plant, $1.58 \mathrm{~kg}$ SS per plant, and $1.33 \mathrm{~kg}$ of DS per plant (Table 2).

The experimental units consisted of pots with $10 \mathrm{dm}^{3}$ capacity, filled with $8 \mathrm{dm}^{3}(10.4 \mathrm{~kg})$ of air-dried soil, passed through a $4 \mathrm{~mm}$ sieve and mixed with the treatments mentioned above. The pineapple seedlings were the young type of cultivar Pérola, from tissue culture, and one seedling was planted per experimental unit. After planting and throughout the growing period, the pineapple seedlings were irrigated, keeping the soil moisture close to the field capacity.

Soil collection for phthalates quantification was carried out at the pineapple flowering beginning, at ten cultivation months. The collection was performed using a cylindrical metal collector and then the soil samples were air dried, passed through a $2 \mathrm{~mm}$ sieve and stored in paper bags.

The fruits were collected at the cultivation cycle end when they were approximately $50 \%$ of their yellowish area. Afterwards, fruit pulp sample was taken, which was crushed in stainless blender and stored in glass container for further phthalates analysis.

\subsection{Phthalates extraction in sludge, soil, and pineapple}

The extraction of phthalates DMP, DBP, and DEHP in sewage sludge, soil and pineapple were carried out using solidliquid extraction with low temperature purification (SLE-LTP). The sewage sludge and soil samples were analyzed using 
methodologies proposed by Pereira et al. (2019).

On the other hand, the extraction of phthalates in pineapple was carried out by transferring $3.0 \mathrm{~g}$ of the sample to a glass vial $(22 \mathrm{~mL})$ and then $2 \mathrm{~mL}$ of distilled water and $8 \mathrm{~mL}$ of acetonitrile were added. The system was homogenized in vortex for 1 minute and subjected to freezing at $-20{ }^{\circ} \mathrm{C}$, for 3 hours. After that period, $2.5 \mathrm{~mL}$ of the organic phase was transferred to a glass test tube containing $350 \mathrm{mg}$ of anhydrous sodium sulfate, homogenized for 1 minute and centrifuged at $4000 \mathrm{rpm}$ for 10 minutes. Subsequently, $1 \mathrm{~mL}$ of the supernatant was transferred to the injection vial and analyzed by gas chromatography-mass spectrometry (GC-MS).

\subsection{Chromatographic analysis}

The quantification of the three phthalates (DMP, DBP, and DEHP) was performed in a gas chromatograph (Agilent Technologies - GC 7890A) coupled to the mass spectrometer (Agilent Technologies - MS 5975C). The instrument control and data acquisition were done using the ChemStation software (E.02.02.1431 copyright@ 1989-2011) from Agilent Technology.

Soil phthalates levels, after cultivation and in the sewage sludge, were determined using an analytical curve from 0.01 to $0.30 \mathrm{mg} \mathrm{kg}^{-1}$ of DMP, DBP, and DEHP. For the pineapple pulp, an analytical curve of 0.005 to $0.225 \mathrm{mg} \mathrm{kg}^{-1} \mathrm{of} \mathrm{DMP}$, DBP, and DEHP was used.

The data were submitted to analysis of variance (ANOVA) and the treatment averages were compared by the ScottKnott test at 0.05 of probability, by the software R version 3.6.3 (R Core Team, 2013).

\section{Results and Discussion}

\subsection{Phthalates in Cambisolo Háplico samples}

In the Cambisolo Háplico sample used in this study, the DMP (dimethyl phthalate) presence was not detected, however, contents of 0.015 and $0.021 \mathrm{mg} \mathrm{kg}^{-1}$ for DBP (dibutyl phthalate) and DEHP (diethyl hexyl phthalate) were found, respectively (Table 2). These values are lower than the maximum limits established for soil prevention, according to CONAMA Resolution No 420 (Brasil, 2009), which is $0.25,0.70$, and $0.60 \mathrm{mg} \mathrm{kg}^{-1}$, respectively, for DMP, DPB, and DEHP.

\subsection{Phthalates in soil samples fertilized with sewage sludge}

After pineapple cultivation, DMP (dimethyl phthalate) was quantified in soil samples from all treatments (Figure 1A). This substance quantification in control and mineral fertilization treatments allows inferring that there was DMP contribution by the better water used in irrigation, which may have been contaminated by the pesticides systematic use in the cultivation area (Sui et al. 2014, Ning et al. 2017). Anyway, treatments can be separated in relation to DMP levels in three main groups: the first formed by $\mathrm{C}$ treatment, with higher content of DMP, the second formed by MF, CS, and VS, with intermediate levels, and the third formed by SS, DS and CaS, with lower levels.

The explanation for the fact mentioned above is that CaS and DS promoted less DMP input compared to the other sewage sludge (Table 2). In addition, the SS, as it is less decomposed, may have undergone more intense action by microorganisms, causing a greater DMP reduction.

The higher DMP levels in treatments CS and VS compared to SS and DS can also be explained by the decomposition degrees of these sewage sludges. In CS and VS, the organic matter was already much moisturized, promoting the diffusion of DMP in the humus porous matrix by adhesion and cohesion forces (van der Waals molecular forces). In this hydrophobic sorption, the moisturized soil organic matter acts as a solubilizing place for substances dissolved in water, analogous to octanol, with DMP partitioning into two phases (solution and soil organic matter) or by dissolution exclusively, that the less polar the substance, greater the tendency to be partitioned in the hydrophobic phase. Thus, DMP in CS and VS treatments were 
retained in the soil by hydrophobic partition, with low levels in the soil solution, and less availability for microbial degradation and plant absorption, when compared to SS and DS treatments (Silva, 2005, O'Connor, 1996).

Anyway, when compared to the control $\left(0.069 \mathrm{mg} \mathrm{kg}^{-1}\right)$, the treatments with mineral fertilization $\left(0.047 \mathrm{mg} \mathrm{kg}^{-1}\right)$ and sewage sludge $\left(0.031,0.012,0.017,0.046\right.$ and $0.039 \mathrm{mg} \mathrm{kg}^{-1}$ for SS, CaS, LD, CS, and VS, respectively) promoted a greater reduction in soil DMP levels, which can be attributed to better fertility and, consequently, greater soil biological activity.

However, in the case of DBP, DEHP, and $\sum$ DP, there were no differences between treatments $(\mathrm{p}>0.05)($ Figs. 1B, 1C and 1D), despite the differences in these substances contribution by sewage sludge treatments (Table 2).

Figure 1. Contents of dimethyl phthalate (DMP) (a), dibutyl phthalate (DBP) (b), diethyl hexyl phthalate (DEHP) (c), and $\sum$ DMP + DBP + DEHP ( $\sum$ DP) (d) in control soil samples (C), mineral fertilization (MF), solarized sludge (SS), sludge with calcium oxide (CaS), dried sludge (DS), composted sludge (CS), and vermicomposted sludge (VS). For each phthalate compound, bars with the same letter showed no statistical difference at 0.05 of probability by the Scott-Knott test
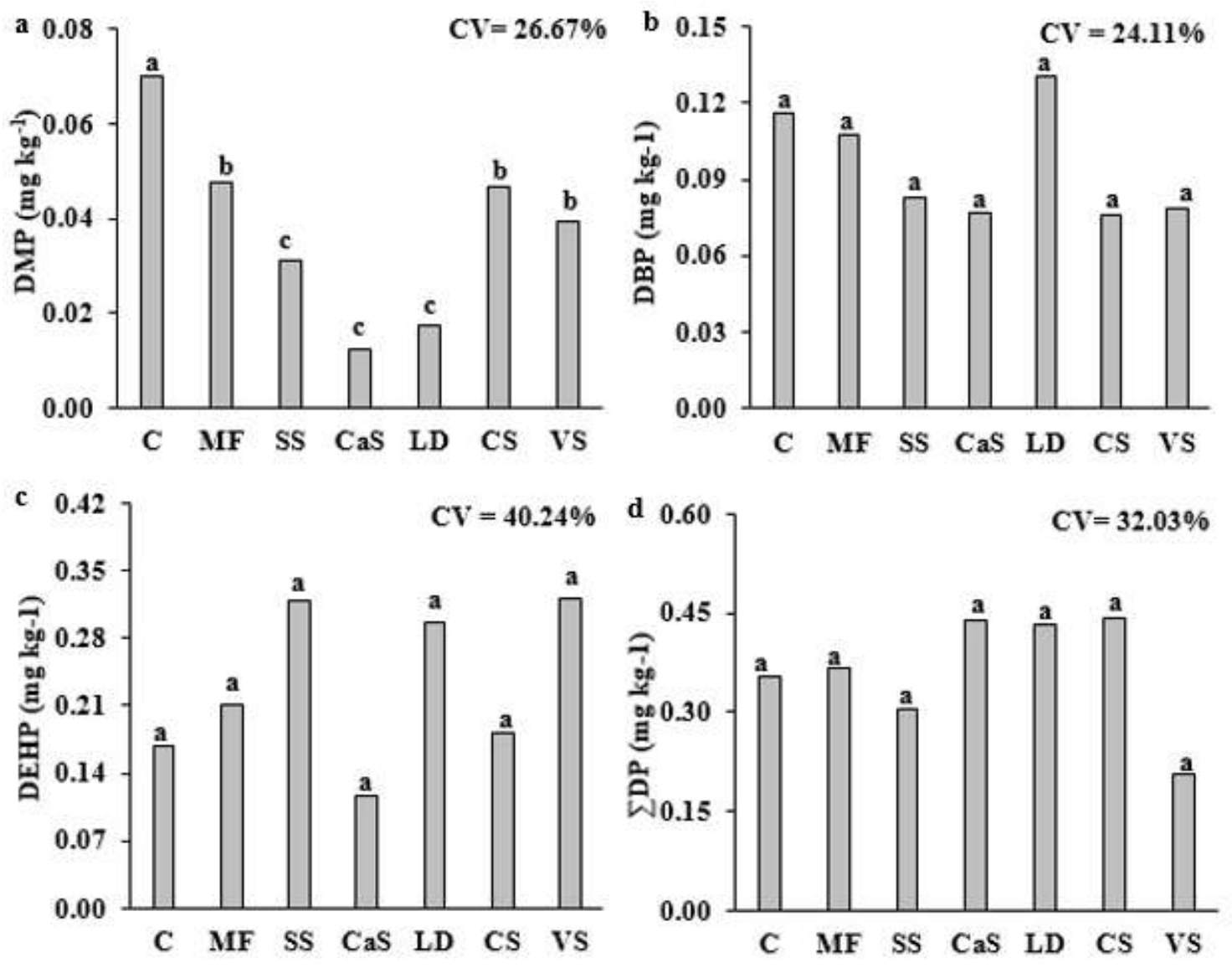

Source: Authors.

DEHP, followed by DBP, were the most abundant compounds in the present study (Figure 1). This fact corroborates with Roslev et al. (2007), who monitored a sewage treatment plant and found higher levels of DEHP and BBP congeners, followed by DBP and DMP in dehydrated sludge. Thus, these compounds abundance indicates greater population consumption of materials that have these phthalates in their composition. DEHP is widely used in the polymer industries and DBP is used in paints, adhesives, perfume fixers, among others (Meng et al. 2014, Vetta Química, 2015, Chen et al. 2017b).

Regarding the phthalate levels sum ( $\left.\sum \mathrm{DP}\right)$, results indicate that all the sewage sludge sanitization processes were efficient in reducing the soil phthalates levels (Figure 1), thus mitigating human absorption risk. This phthalate levels decrease may be due to processes such as volatilization, leaching, sorption, degradation (biotic and abiotic), among others (O'Connor, 
1996). In abiotic degradation, phthalates generally undergo photochemical and hydrolytic reactions. On the other hand, in biotic processes, degradation occurs due to bacteria, fungi, yeasts and algae action (Benjamin et al. 2015), being these microorganisms action the main pathway for phthalates decomposition in environmental matrices.

Composting reduces phthalate content, mainly of DEHP, and its greatest reduction occurs in the thermophilic phase, which can be degraded by the bacteria Acinetobacter sp. and Micrococcus luteus, among others (Cheng et al. 2008, Pakou et al. 2009, Benjamin et al. 2015). Thus, the composting, solarization and thermal drying techniques are efficient in reducing of sewage sludge phthalates (Bagó et al. 2005, Gibson et al. 2007).

DEHP was the phthalate most concentrated in the sewage sludge of the present research, with emphasis on the solarized sewage sludge (SS), which promoted the largest contribution of this substance (Table 2). Thus, considering the critical prevention level of $0.6 \mathrm{mg} \mathrm{kg}^{-1}$ of DEHP in the soil, required by CONAMA Resolution No 420/2009 (Brazil, 2009), and the content already existing in the soil (Table 1), it is estimated that pineapple fertilization with SS could be carried out a maximum of 6.6 times consecutively. In contrast, if composted sewage sludge (CS) were applied, with the lowest DEHP input, the number of times to reach the critical level would be 49.3. These values do not consider soil phthalates losses resulting from degradation processes or in other ways.

\subsection{Phthalate in pineapple fruit treated with sewage sludge}

DMP levels in the pineapple pulp were statistically similar between treatments (Figure 2), with values ranging from 0.02 to $0.04 \mathrm{mg} \mathrm{kg}^{-1}$, while DBP levels were below the quantification limit by the analysis method used, which was $0.005 \mathrm{mg}$ $\mathrm{kg}^{-1}$.

In DEHP case, fruits from treatments with mineral fertilization (MF) and composted sludge (CS) had the DEHP highest levels (Figure 2), with averages of 0.15 and $0.11 \mathrm{mg} \mathrm{kg}^{-1}$, respectively. However, for the other treatments, there were no significant differences between them, with values ranging from 0.02 to $0.08 \mathrm{mg} \mathrm{kg}^{-1}$.

For $\sum \mathrm{DP}$, the behavior was the same observed for the DEHP congener (Figure 2), with highest values occurring in MF and CF treatments, with respective values of 0.19 and $0.14 \mathrm{mg} \mathrm{kg}^{-1}$. In this case, there were also no significant differences between the other treatments, with a variation between the means of 0.05 to $0.10 \mathrm{mg} \mathrm{kg}^{-1}$. 
Figure 2. Contents of dimethyl phthalate (DMP) (a), diethyl hexyl phthalate (DEHP) (b), and $\sum D P(D M P+D B P+D E H P)(c)$ in fresh pineapple pulp sample of control (C), mineral fertilization (MF), solarized sludge (SS), sludge with calcium oxide $(\mathrm{CaS})$, dried sludge (DS), composted sludge (CS), and vermicomposted sludge (VS). For each phthalate compound, bars with the same letter showed no statistical difference at 0.05 of probability by the Scott-Knott test
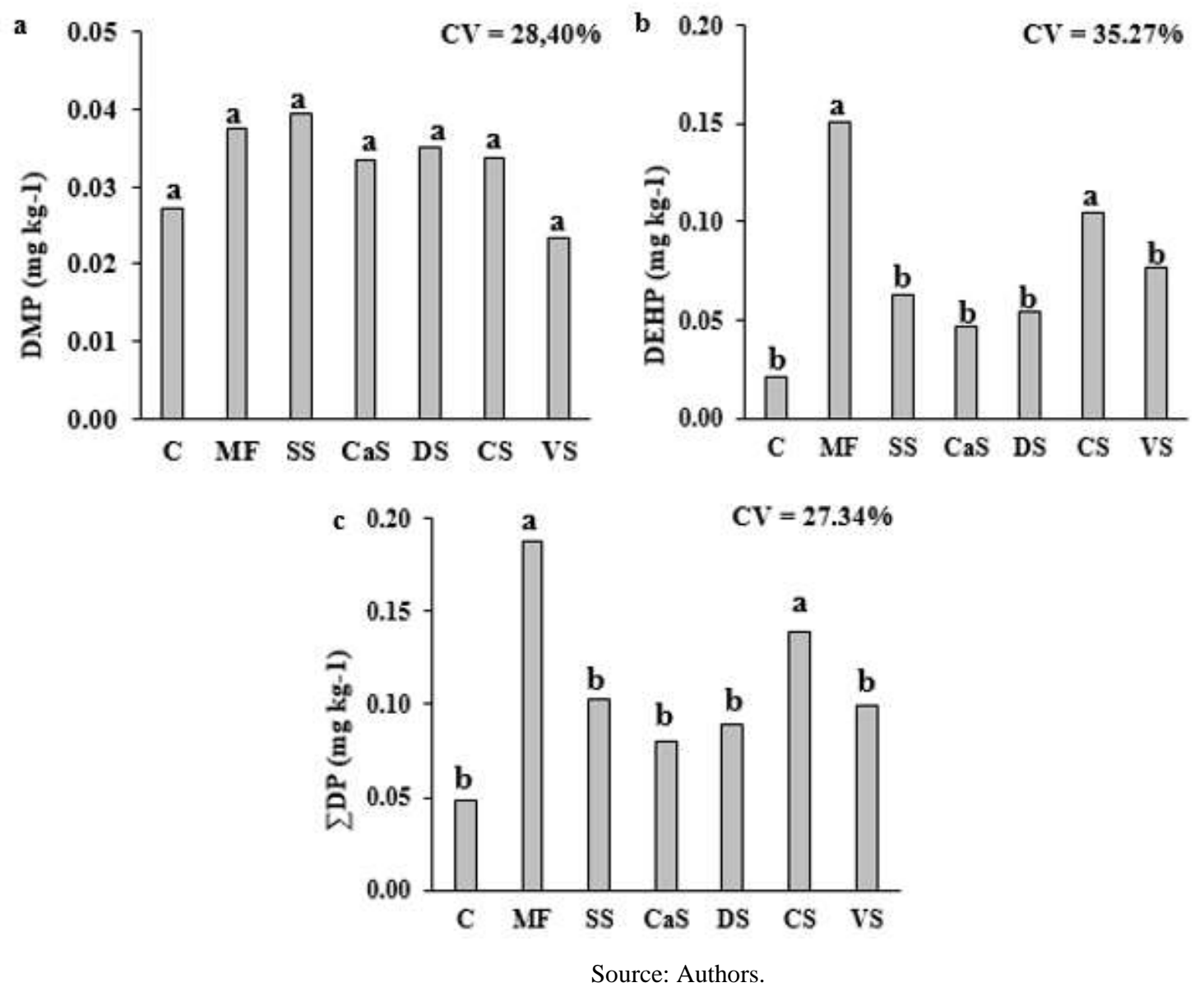

Comparing the two congeners absorbed by the fruits, DEHP was absorbed in greater quantity than DMP (Figure 2), possibly due to its higher initial soil content and greater contribution through fertilization (Tables 1 and 2). However, DEHP has a higher molar mass, partition coefficient (Log Kow) and hydrophobicity, which would imply greater sorption by the soil's organic matter duo to its absorption by the plant (Cheng et al. 2008, Wang et al. 2015, Lin et al. 2017).

In Brazil, there is still no legislation that determines the maximum phthalate limit that can be ingested by humans without causing adverse health effects. However, according to Barros (2010), the acceptable daily intake of DEHP is $25 \mu \mathrm{g}$ kg${ }^{1}$ of body weight per day for a man of $1.70 \mathrm{~m}$ height and $60 \mathrm{~kg}$ of body mass. In addition, the National Health Surveillance Agency (ANVISA) through the " Technical regulation on the positive list of additives for plastic materials intended for the packaging and equipment preparation in contact with food " determines that the acceptable migration limit of food packaging is 0.3 and $1.5 \mathrm{mg} \mathrm{kg}^{-1}$ of DBP and DEHP, respectively (Brasil, 2008).

Thus, considering the higher DEHP content observed in the pineapple fresh fruit (Figure 2), which was $0.15 \mathrm{mg} \mathrm{kg}^{-1}$, and the daily intake of two pineapple slices with total fresh mass estimated at $180 \mathrm{~g}$ by one person of $60 \mathrm{~kg}$ of body mass, the rate of this substance ingestion would be only $0.45 \mu \mathrm{g} \mathrm{kg}^{-1} \mathrm{day}^{-1}$, that is, less than $2 \%$ of the maximum tolerable limit. In addition, the highest fruit DEHP content corresponded to only $10 \%$ of the maximum content allowed in food due to contact with plastics. 
Therefore, regardless of the fertilization type, the phthalate congener's levels in pineapple pulp were below the critical safety limits for this food consumption. It is worthy to mention that the present study evaluated the DMP, DBP, and DEHP congeners and did not consider pathogens and other contaminants that may be present in sewage sludge. And it is necessary to do more studies to understand the influence of those contaminants in pineapple cultivation treated with sewage sludge.

\section{Conclusion}

Fertilization with solarized, dried, sanitized with calcium oxide sewage sludge provides the dimethyl phthalate (DMP) lowest levels in soil cultivated with pineapple.

For pineapple pulp, fertilization with solarized, dried, sanitized with calcium oxide, and vermicomposted sewage sludge provides the lowest levels of diethyl hexyl phthalate (DEHP).

The fertilization with sewage sludge maintains the levels of dimethyl phthalate (DMP), dibutyl phthalate (DBP), and diethyl hexyl phthalate (DEHP) in soils, below the maximum limits for prevention, established by Brazilian environmental legislation.

Diethylexyl phthalate (DEHP) is the phthalate with the highest content in the soil and in the pineapple pulp, while dibutyl phthalate (DBP) is not quantified in the fruit.

The phthalate congener's contents in pineapple pulp were much below than the critical safety limits for this food consumption.

Finally, as a way to advance the scientific knowledge presented in this study, future investigations approaching analyzes of pathogens and other contaminants that may be present in sewage sludge.

\section{Acknowledgments}

The present research was carried out with support from the National Academic Cooperation Program of the Coordination for the Improvement of Higher Education Personnel (CAPES/Brazil), Institute of Agricultural Sciences from Federal University of Minas Gerais - (ICA-UFMG), National Council for Scientific and Technological Development (CNPq) and Research Support Foundation of Minas Gerais State (FAPEMIG).

\section{References}

Alvares, C.A., Stape, J.L., Sentelhas, P.C., Gonçalves, J.L.M., Sparovek, G. (2013). Köppen's climate classification map for Brazil. Meteorologische Zeitschrift, 22, 711-728. https://doi.org/10.1127/0941-2948/2013/0507

Bagó, B., Martín, Y., Mejía. G., Broto-Puig, F., Díaz-Ferrero, J., Agut, M., Comellas, L. (2005). Di-(2-ethylhexyl)phthalate in sewage sludge and post-treated sludge: Quantitative determination by HRGC-MS and mass spectral characterization. Chemosphere, 59, 1191-1195. https://doi.org/10.1016/j.chemosphere.2004.11.077

Barros, H. D. Estudo da exposição do consumidor aos plastificantes ftalato e adipato de di-(2-etil-hexila) adicionados a filmes de pvc, utilizados para acondicionamento de alimentos gordurosos. Instituto Nacional de Controle de Qualidade em Saúde, Fundação Oswaldo Cruz.

Benjamin, S., Pradeepa, S., Josha, M.S., Kumarb, S., Masaic, E. (2015). A monograph on the remediation of hazardous phthalates. Journal of Hazardous Materials, 298, 58-72. https://doi.org/10.1016/j.jhazmat.2015.05.004

BRASIL (2009). Conselho Nacional do Meio Ambiente - CONAMA. Resolução $\mathrm{N}^{\circ} 420$, de 28 de dezembro de 2009. http://www.mma.gov.br/port/conama/legiabre.cfm?codlegi=620 .

BRASIL. (2008) Ministério da Saúde. Agência Nacional de Vigilância Sanitária. Resolução $\mathrm{n}^{\circ} 17$, de 17 de março de 2008. http://portal.anvisa.gov.br/documents/33880/2568070/res0017_17_03_2008.pdf/5710c792-2d7d-4e74-91c5-b63b86edcdae

BRASIL (2006) Conselho Nacional de Meio Ambiente- CONAMA. Resolução n ${ }^{\circ} 375$, de 29 de Agosto de 2006. July 17, 2020, http://www.mma.gov.br/port/conama/res/res06/res37506.pdf

Chen, C. F., Chen, C. W., Ju, Y. R., \& Dong, C. D. (2017b). Determination and assessment of phthalate esters content in sediments from Kaohsiung Harbor, Taiwan. Marine Pollution Bulletin, 124(2), 767-774. https://doi.org/10.1016/j.marpolbul.2016.11.064 
Chen, Q., Yang, H., Zhou, N., Sun, L., Bao, H., Tan, L., ... \& Li, L. (2017a). Phthalate exposure, even below US EPA reference doses, was associated with semen quality and reproductive hormones: Prospective MARHCS study in general population. Environment international, 104, 58-68. https://doi.org/10.1016/j.envint.2017.04.005

Cheng, H. F., Kumar, M., Lin, J. G. (2008). Degradation kinetics of di-(2-ethylhexyl) phthalate (DEHP) and organic matter of sewage sludge during composting. Journal of Hazardous Materials, 154, 55-62. https://doi.org/10.1016/j.jhazmat.2007.09.105

Chang, W. H., Herianto, S., Lee, C. C., Hung, H., \& Chen, H. L. (2021). The effects of phthalate ester exposure on human health: A review. Science of the Total Environment, 147371. https://doi.org/10.1016/j.scitotenv.2021.147371

EMBRAPA (1997). Manual de métodos de análise de solo.

Florentino, A. L., Ferraz, A.V., Gonçalves, J. L. M., Asensio, V., Muraoka, T., Dias, C. T. S., Nogueira, A. R., Capra, G. F., Abreu-Junior, C. H. (2019). Long-term effects of residual sewage sludge application in tropical soils under Eucalyptus plantations. Journal of Cleaner Production, 220 , 177-187. https://doi.org/10.1016/j.jclepro.2019.02.065

Gibson, R. W., Wang, M. J., Padgett, E., Lopez-Real, J. M., Beck, A. J. (2007). Impact of drying and composting procedures on the concentrations of 4nonylphenols, di-(2-ethylhexyl)phthalate and polychlorinated biphenyls in anaerobically digested sewage sludge. Chemosphere, 68, 1352-1358. https://doi.org/10.1016/j.chemosphere.2007.01.020

IBGE- (2019). Produção Agrícola. Retrieved July 09, 2021, from https://cidades.ibge.gov.br/brasil/pesquisa/14/10193

Ignatowicz, K. (2017). The impact of sewage sludge treatment on the content of selected heavy metals and their fractions. Environmental Research, 156, 1922. https://doi.org/10.1016/j.envres.2017.02.035

Karačonji, B., Jurica, S. A., Lasić, D., Jurica, K. (2017). Facts about phthalate toxicity in humans and their occurrence in alcoholic beverages. Archives of Industrial Hygiene and toxicology, 68, 81-92. https://doi.org/10.1515/aiht-2017-68-2951

Leonardo, F. D. A. P., Pereira, W. E., Dias, T. J., de Moura, J. G., Véras, M. L. M., Leal, Y. H. (2019) Chemical Soil Attributes, Accumulation of Foliar Macronutrients and Productivity of the 'Vitória' Pineapple Plant Fertilized with Urea and Chicken Manure. Jornal da Agricultura Experimental Internacional, 1-10. https://doi.org/10.9734/jeai/2019/v31i230067

Li, J., Qian, X., Zhao, H., Zhou, Y., Xu, S., Li, Y., ... \& Cai, Z. (2019). Determinants of exposure levels, metabolism, and health risks of phthalates among pregnant women in Wuhan, China. Ecotoxicology and environmental safety, 184, 109657. https://doi.org/10.1016/j.ecoenv.2019.109657

Lin, Q., Chen, S., Chao, Y., Huang, X., Wang, S. (2017). Rongliang Qiu Carboxylesterase-involved metabolism of di-n-butyl phthalate in pumpkin (Cucurbita moschata) seedlings Environmental Pollution, 220, 421-430. https://doi.org/10.1016/j.envpol.2016.09.084

Martín-Díaz, J., Lucena, F., Blanch, A. R., \& Jofre, J. (2020). Indicator bacteriophages in sludge, biosolids, sediments and soils. Environmental Research, 109133. https://doi.org/10.1016/j.envres.2020.109133

Macedo, J. A. B. (2011). Química ambiental: Uma ciência ao alcance de todos.

Melo, W., Delarica, D., Guedes, A., Lavezzo, L., Donha, R., De Araújo, A., de Melo, G., Macedo, F. (2018). Ten years of application of sewage sludge on tropical soil. A balance sheet on agricultural crops and environmental quality. Science of The Total Environmental, 643, 1493-1501. https://doi.org/10.1016/j.scitotenv.2018.06.254

Meng, X. Z., Wang, Y., Xiang, N., Chen, L., Liu, Z., Wu, B., ... \& Ebinghaus, R. (2014). Flow of sewage sludge-borne phthalate esters (PAEs) from human release to human intake: implication for risk assessment of sludge applied to soil. Science of the Total Environment, 476, $242-249$. https://doi.org/10.1016/j.scitotenv.2014.01.007

Mota, M. F., Pegoraro, R. F., Santos, S. R. D., Maia, V. M., Sampaio, R. A., \& Kondo, M. K. (2018). Contamination of soil and pineapple fruits under fertilization with sewage sludge. Revista Brasileira de Engenharia Agrícola e Ambiental, 22(5), 320-325. https://doi.org/10.1590/18071929/agriambi.v22n5p320-325

Nascimento, A. L., Sampaio, R. A., Cruz, S. F. D., Zuba Junio, G. R., Barbosa, C. F., \& Fernandes, L. A. (2014). Metais pesados em girassol adubado com lodo de esgoto submetido a diferentes processos de estabilização. Revista Brasileira de Engenharia Agrícola e Ambiental, 18(7), 694-699. https://doi.org/10.1590/S1415-43662014000700004

Ning, C., Wenjuan, S., Xinmei, H., Huichun, Z., Dongmei, Z., Juan, G. (2017). Contamination of Phthalate Esters in Vegetable Agriculture and Human Cumulative Risk Assessment. Pedosphere, 27(3), 439-451. https://doi.org/10.1016/S1002-0160(17)60340-0

O'connor, G. A. (1996). Organic compounds in sludge-amended soils and their potential for uptake by crop plants. Science of the Total Environment, 185, 7181. https://doi.org/10.1016/0048-9697(95)05043-4

Pakou. C., Kornaros, M., Stamatelatou, K., Lyberatos, G. (2009). On the fate of LAS, NPEOs and DEHP in municipal sewage sludge during composting. Bioresource Technology, 100, 1634-1642. https://doi.org/10.1016/j.biortech.2008.09.025

Pereira, N. G., Silvério, F. O., \& Pinho, G. P. (2019). Optimisation, validation and application of the solid-liquid extraction with low-temperature purification followed by gas chromatography-mass spectrometry for determination of phthalates in sewage sludge. International Journal of Environmental Analytical Chemistry, 100(9), 968-980. https://doi.org/10.1080/03067319.2019.1646735

Podlecka, D., Gromadzińska, J., Mikołajewska, K., Fijałkowska, B., Stelmach, I., \& Jerzynska, J. (2020). Longitudinal impact of phthalates exposure on allergic diseases in children. Annals of Allergy, Asthma \& Immunology. https://doi.org/10.1016/j.anai.2020.03.022

R Core Team (2013). R: A language and environment for statistical computing. 
Research, Society and Development, v. 10, n. 9, e9810917659, 2021

(CC BY 4.0) | ISSN 2525-3409 | DOI: http://dx.doi.org/10.33448/rsd-v10i9.17659

Roslev, P., Vorkamp, K., Aarup, J., Frederiksen, K., \& Nielsen, P. H. (2007). Degradation of phthalate esters in an activated sludge wastewater treatment plant. Water research, 41(5), 969-976. https://doi.org/10.1016/j.watres.2006.11.049

Santos, D. S., Teshima, E., Dias, S. M. F., Araújo, R. A., \& Silva, C. M. R. D. (2017). Efeito da secagem em leito nas características físico-químicas e microbiológicas de lodo de reator anaeróbio de fluxo ascendente usado no tratamento de esgoto sanitário. Engenharia Sanitaria e Ambiental, 22(2), 341-349. https://doi.org/10.1590/s1413-41522016100531

Silva, B. C. de P. (2005) Elementos finitos para modelagem da sorção de contaminantes orgânicos na fração orgânica dos solos. Instituto Tecnológico de Aeronáutica.

Song, F., Gu, L., Zhu, N., Yuan, H. (2013). Leaching behavior of heavy metals from sewage sludge solidified by cement-based binders. Chemosphere, 92(4), 344-350. https://doi.org/10.1016/j.chemosphere.2013.01.022

Souza, M. de, Guimarães, P. T. G., Carvalho, J. G. de, \& Fragoas, J. C. (1999). Sugestões de adubação para plantas frutíferas: Abacaxizeiro. In A. C. Ribeiro, P. T. G. Guimarães, \& V. V. H. Alvarez (Eds.). Recomendações para o uso de corretivos e fertilizantes em Minas Gerais (1th ed., pp. 209-216).

Sui, H. X., Zhang, L., Wu, P. G., Song, Y., Yong, L., Yang, D. J., Jiang, D. G., Liu, Z. P. (2014). Concentration of di(2-ethylhexyl) phthalate (DEHP) in foods and its dietary exposure in China. International Journal of Hygiene and Environmental Health, 217, 695-701. https://doi.org/10.1016/j.ijheh.2014.02.006

Urbaniak, M., Wyrwicka, A., Tołoczko, W., Serwecińska, L., Zieliński, M. (2017). The effect of sewage sludge application on soil properties and willow (Salix sp.) cultivation. Science of the Total Environment, 586, 66-75. https://doi.org/10.1016/j.scitotenv.2017.02.012

Vetta Química (2015, July 22). Ficha técnica Dibutil ftalato DBP. http://www.vettaquimica.com.br/wp-content/uploads/2010/06/DiButil-Ftalato-DBPETTAPLAST-4.pdf

Wang, J., Chen, G., Christie, P., Zhang, M., Luo, Y., Teng, Y. (2015). Occurrence and risk assessment of phthalate esters (PAEs) in vegetables and soils of suburban plastic film greenhouses. Science of the Total Environment, 523, 129-137. https://doi.org/10.1016/j.scitotenv.2015.02.101 